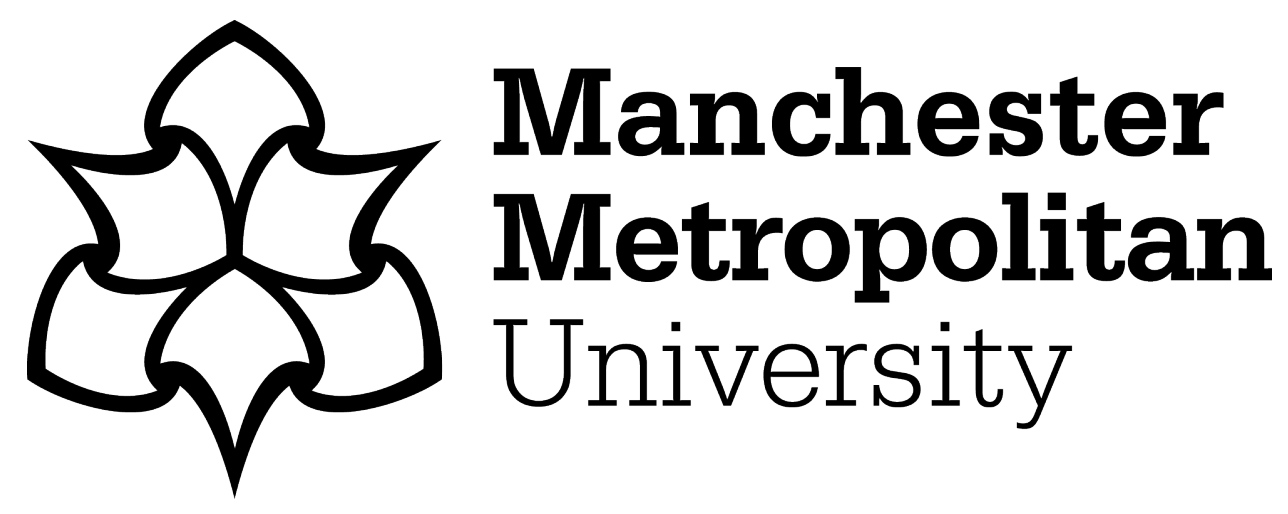

Muthee, KW, Mbow, C, Macharia, GM and Leal-Filho, W (2017) Ecosystem services in adaptation projects in West Africa. International Journal of Climate Change Strategies and Management, 10 (4). pp. 533-550. ISSN 17568692

Downloaded from: https://e-space.mmu.ac.uk/621033/

Publisher: Emerald

DOI: https://doi.org/10.1108/JJCCSM-06-2017-0140

Usage rights: Creative Commons: Attribution 4.0

Please cite the published version 


\section{e emeraldinsight}

\section{International Journal of Climate Change Strategies and Management}

Ecosystem services in adaptation projects in West Africa

Kennedy Wahome Muthee, Cheikh Mbow, Geoffrey Mugo Macharia, Walter Leal-Filho,

\section{Article information:}

To cite this document:

Kennedy Wahome Muthee, Cheikh Mbow, Geoffrey Mugo Macharia, Walter Leal-Filho, (2018)

"Ecosystem services in adaptation projects in West Africa", International Journal of Climate

Change Strategies and Management, Vol. 10 Issue: 4, pp.533-550, https://doi.org/10.1108/

IJCCSM-06-2017-0140

Permanent link to this document:

https://doi.org/10.1108/lJCCSM-06-2017-0140

Downloaded on: 06 J uly 2018, At: 03:41 (PT)

References: this document contains references to 30 other documents.

The fulltext of this document has been downloaded 441 times since 2018*

\section{Users who downloaded this article also downloaded:}

(2018),"Mainstreaming climate change into the EIA procedures: a perspective from China", International Journal of Climate Change Strategies and Management, Vol. 10 Iss 3 pp.

342-358 <a href="https://doi.org/10.1108/lJCCSM-04-2016-0040">https://doi.org/10.1108/

IJCCSM-04-2016-0040</a>

(2018),"Resource extractivism, health and climate change in small islands", International Journal of Climate Change Strategies and Management, Vol. 10 Iss 2 pp. - <a href="https://doi.org/10.1108/ IJCCSM-03-2017-0068">https://doi.org/10.1108/IJCCSM-03-2017-0068</a>

\section{Wencherstry}

Access to this document was granted through an Emerald subscription provided by All users group

\section{For Authors}

If you would like to write for this, or any other Emerald publication, then please use our Emerald for Authors service information about how to choose which publication to write for and submission guidelines are available for all. Please visit www. emeraldinsight.com/ authors for more information.

\section{About Emerald www.emeraldinsight.com}

Emerald is a global publisher linking research and practice to the benefit of society. The company manages a portfolio of more than 290 journals and over 2,350 books and book series volumes, as well as providing an extensive range of online products and additional customer resources and services.

Emerald is both COUNTER 4 and TRANSFER compliant. The organization is a partner of the Committee on Publication Ethics (COPE) and also works with Portico and the LOCKSS initiative for digital archive preservation. 
*Related content and download information correct at time of download. 


\title{
Ecosystem services in adaptation projects in West Africa
}

\author{
Kennedy Wahome Muthee \\ Department of Environmental Science, School of Environmental Studies, \\ Kenyatta University, Nairobi, Kenya \\ Cheikh Mbow \\ START International, Washington, DC, USA \\ Geoffrey Mugo Macharia \\ Department of Environmental Science, School of Environmental Studies, \\ Kenyatta University, Nairobi, Kenya, and \\ Walter Leal-Filho \\ HAW Hamburg, Hamburg, Germany and Manchester Metropolitan University, \\ Manchester, UK
}

\begin{abstract}
Purpose - The purpose of this paper is to assess the extent to which adaptation projects have incorporated ecosystem services, as well as their redesigning options. The projects selected are listed under National Adaptation Programme of Action in West African region.

Design/methodology/approach - A desktop survey approach was used to review 168 projects from 13 countries across West Africa. The projects were categorized and analyzed according to their adaptation goal, thematic focus, their implementation duration and level of investment.

Findings - The adaptation initiatives are dominated by actions in the agricultural sector accounting for 32 per cent of the total. Further, they were characterized by small grants consideration with 63 per cent falling under US $\$ 1 \mathrm{~m}$ budget, short-term implementation duration with 46 per cent having three years' execution period. A large portion of projects (55 per cent) mentioned directly one or more ecosystem services, with provisioning services being referred to in 50 per cent of the cases.

Originality/value - Adaptation projects with ecosystem services components are more sustainable and beneficial to the community. Hence, more consideration of nature benefits during project design, more financial consideration and localizing of the projects to realize the global adaptation goal should be considered.
\end{abstract}

Keywords Climate change, Adaptation, West Africa, Ecosystem services,

National Adaptation Programmes of Action (NAPAs)

Paper type Research paper

(C) Kennedy Wahome Muthee, Cheikh Mbow, Geoffrey Mugo Macharia and Walter Leal-Filho. Published in International Journal of Climate Change Strategies and Management. Published by Emerald Publishing Limited. This article is published under the Creative Commons Attribution (CC BY 4.0) licence. Anyone may reproduce, distribute, translate and create derivative works of this article (for both commercial and non-commercial purposes), subject to full attribution to the original publication and authors. The full terms of this licence may be seen at http:// creativecommons.org/licences/by/4.0/legalcode

The authors are grateful to the BIODEV project funded by the Finland Government under the CGIAR Research Programs (CRP) 6.3 and 6.4.

This paper forms part of a special section "Climate change and biodiversity assets", guest edited by Ulisses Azeiteiro.

Ecosystem services in adaptation projects

533

Received 16 June 2017 Revised 16 August 2017

12 September 2017

14 September 2017 Accepted 14 September 2017 


\section{IJCCSM \\ 10,4}

\section{Background and introduction}

Ecosystems play an irreplaceable role in supporting life through provision of ecosystem services (Colls et al., 2009), which maintain, strengthen and enrich different elements of livelihood on the planet (Capistrano, 2005). The functional dependency between trees, water, soil, vegetation, animals and humans (Melillo et al., 2003) supports sustained values for life on the planet as Bailey (2009) notes. The Millennium Ecosystems Assessment Report MEA (2005) - categorizes these benefits into four main classes: supporting, provisional, regulating and cultural. Notably, the ability of the ecosystems to deliver ecosystem services (ES) depend on their condition (healthy state) as well as the ability of society to access them accordingly (Pramova et al., 2012).

Despite the essential services provided by ecosystems, the majority of them are under threat globally as a result of their degradation (MEA, 2005). Some of the major threats facing the existence and services provision of ecosystems include ecosystem conversion, climate change, loss of biodiversity as well as destruction and unsustainable extraction of resources from sensitive ecosystems such as forests and wetlands (Boyd and Banzaf, 2007; Brouwer et al., 2011; Michelle et al., 2012). Munang (2013) estimates that 60 per cent of global ecosystem services are either being unsustainably used or severely degraded by anthropogenic factors. Further, MEA (2005) establishes that there is a rapid increase in ecosystems degradation in the past 50 years that is not comparable to any other period in the human history. Some of the factors leading to this degradation include a high demand for timber and wood products, fuel, water and food according to the Intergovernmental Panel on Climate Change - IPCC (2007; 2014a) reports. The Least Developed Nations (LDCs) globally have the highest rates of ecosystems degradation due to their over-reliance and dependency on the ecosystems for the survival of their citizens (Climate Change Science Program-CCSP, 2008; Brouwer et al., 2011).

The LDCs are at a higher risk of climate change effects. To support the adaptation processes, the United Nation Framework Convention on Climate Change (UNFCCC) passed a policy instrument to assist them in the process of designing the National Adaptation Programme of Action (NAPA) based on the country-specific urgent and immediate adaptation needs (Pramova et al., 2012). This has worked well in some countries (Muchuru and Nhamo, 2017) that have received project funding from the Green Climate Fund (GCF) to cushion them against their identified urgent and immediate need.

From Paris agreement, the Nationally Determined Contributions (NDC) was established as a new policy instrument replacing Kyoto Protocol. NDC is a bottom up approach that integrates adaptation with mitigation through binding the pledges in greenhouse gases reduction with adaptation objectives (Lomborg, 2016). The bundling of the two negotiation themes gives more visibility to land-based adaptation process that will bring the ecosystem services higher up on the responses to climate change. A necessary step is to reassess the NAPAs focal areas and assess the prospect of ecosystem services in achieving adaptation objectives.

The primary purpose of this paper is to determine the extent to which the climate change adaptation projects listed under NAPA in selected countries in West Africa have incorporated ecosystem services and their redesigning options. This was in cognizant to the fact that adaptation projects with ecosystem services components are more sustainable and beneficial to the community. Specifically, the paper assessed different dimensions of adaptation projects in West Africa, evaluated the extent to which they have incorporated ecosystem services and identified areas of redesigning and improving adaptation projects to enhance ecosystem services. 


\section{Study area}

\subsection{Description of study area}

West Africa is one of the regions with highest numbers of LDCs (UNCTAD, 2014), and is known to have a high rate of natural degradation and consequently little economic development. Further, West Africa is among the regions in Africa that have been hard hit by the consequences of climate change, as characterized by the recurrence of episodes of crop failure and droughts that affects social, economic and environmental sectors.

The region is located between $4^{\circ} \mathrm{N}$ and $28^{\circ} \mathrm{N}, 15^{\circ} \mathrm{E}$ and $16^{\circ} \mathrm{W}$. It has four major climatic average annually with prolonged dry periods. It is characterized by natural vegetation such as grassland, shrubs, and acacia trees that support pastoralism and small-scale farming. The sub-humid zone covers upper Guinea, southern Mali, Benin, Northern Ghana, Ivory Coast and Sierra Leone. It receives between 1,250 and 1,500 mm of rain per season. This climatic condition supports grass and shrubs vegetation, as well as wide array of agricultural activities. The river valleys and wetlands within Sub-humid zone also support growth of natural and man-made forests. The last climatic zone is the humid zone which has two distinct sub-climatic zones. The Guinean (Savannah) zone has an annual rainfall of between $1,500 \mathrm{~mm}$ and $1,800 \mathrm{~mm}$, and it cuts across states such as south-east Guinea, Northern Liberia, parts of Ivory Coast, and Middle Ghana. Secondly, the forest zone experiences an annual rainfall is between $1,500 \mathrm{~mm}$ and 2,000 $\mathrm{mm}$ with wet and dry seasons alternating each other. The area has dense tropical forests, which also support a broad range of agricultural activities.

West Africa has 16 countries, of which 13 are categorized as LDCs. The analyzed countries are shown in Figure 1. Notably, both study and non-study countries were included in this map for comparison purposes, and to portray the extent of underdevelopment in the region.

\section{Research methodology \\ 3.1 Research design}

This study took a desktop survey approach in which all projects listed in the countryspecific NAPA were studied. These projects were prepared by the LDCs across the globe under the auspices of the UNFCCC to support them in adapting to the effects of climate change. The criteria for project selection and prioritization was based on:

- the urgent and immediate need for adaptation to climate change; and

- the possibility that further delay could increase vulnerability and higher costs at the later stages.

Notably, the projects studied were those submitted to the UNFCCC for funding consideration after undergoing the conceptualization and design at the specific country level. Thirteen NAPAs with a total of 168 individual projects were analyzed, after which a summary was created in the form of a database for further analysis. The project studies were designed between 2004 and 2009 depending on the country of origin. Table I 


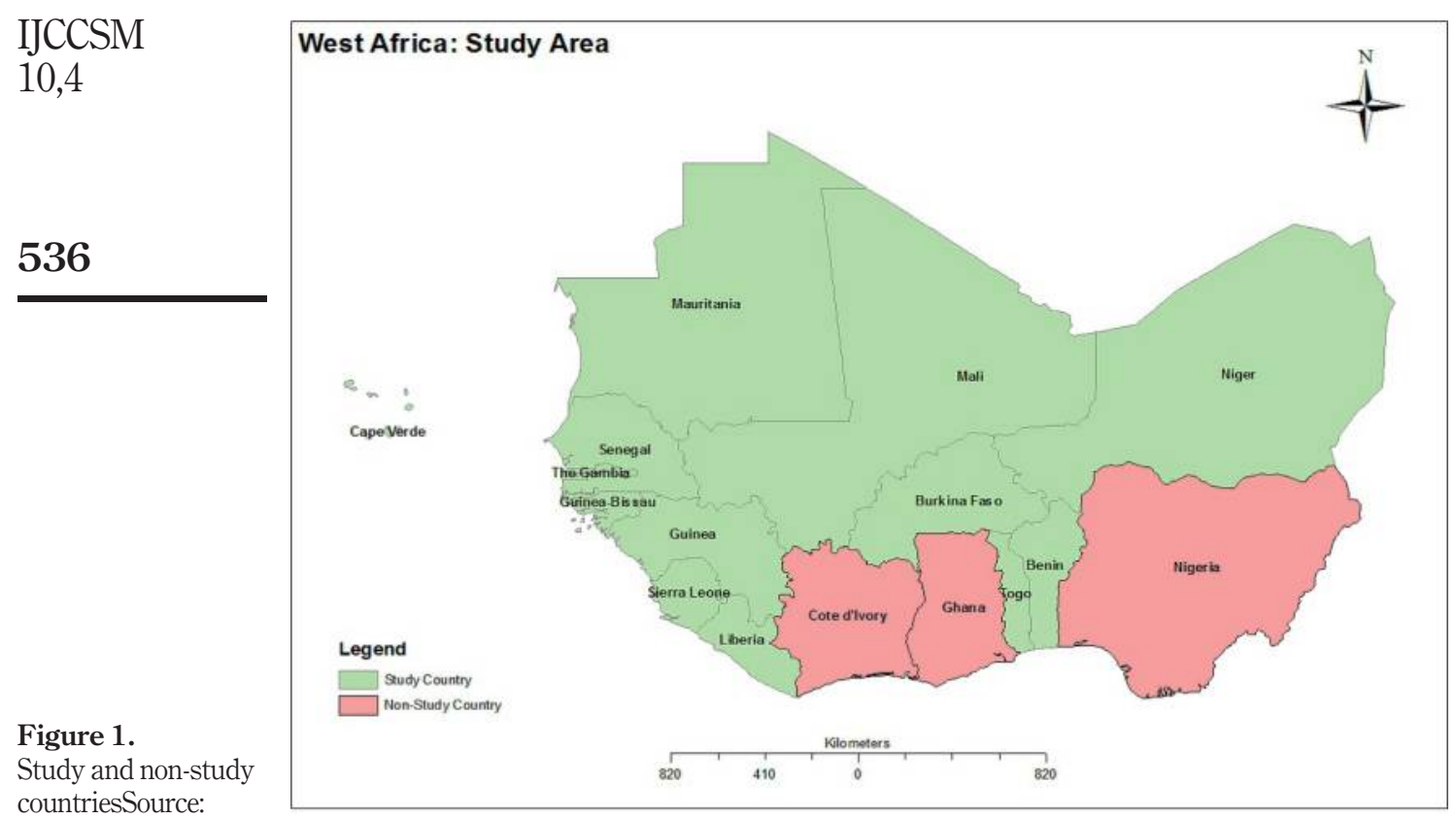

iesSource:

Source: Author

summarizes the projects studied, their year of submission to UNFCCC for consideration and links to the primary source in the UNFCCC portal.

\subsection{Sampling process}

This study reviewed all 168 projects submitted by the specific West African countries to UNFCCC for funding considerations. These projects went through a vigorous process involving different stakeholders and are deemed to be the accurate reflection of the adaptation needs in different countries in West Africa.

\subsection{Research tools}

3.3.1 ArcGIS. ArcGIS is a Geographic Information System tool used for creating, analyzing and displaying geographical information and maps. The tool has various components which allow viewing and querying maps, creating maps and performing spatial analysis. The tool was used in developing the study and non-study areas map in Figure 1 above.

3.3.2 Community-based risk screening tool adaptation and livelihoods - CRiSTAL tool. CRiSTAL, a project planning and management tool, was used to help understand potential climate hazards, the community response to those risks, the livelihood context and how the project activities can be improved or redesigned to enhance adaptation (www.iisd.org/ cristaltool).

\subsection{Projects categorization}

Three broad categories were developed based on how the projects have incorporated ecosystem services. These are projects without expressing any form of ecosystem services, 


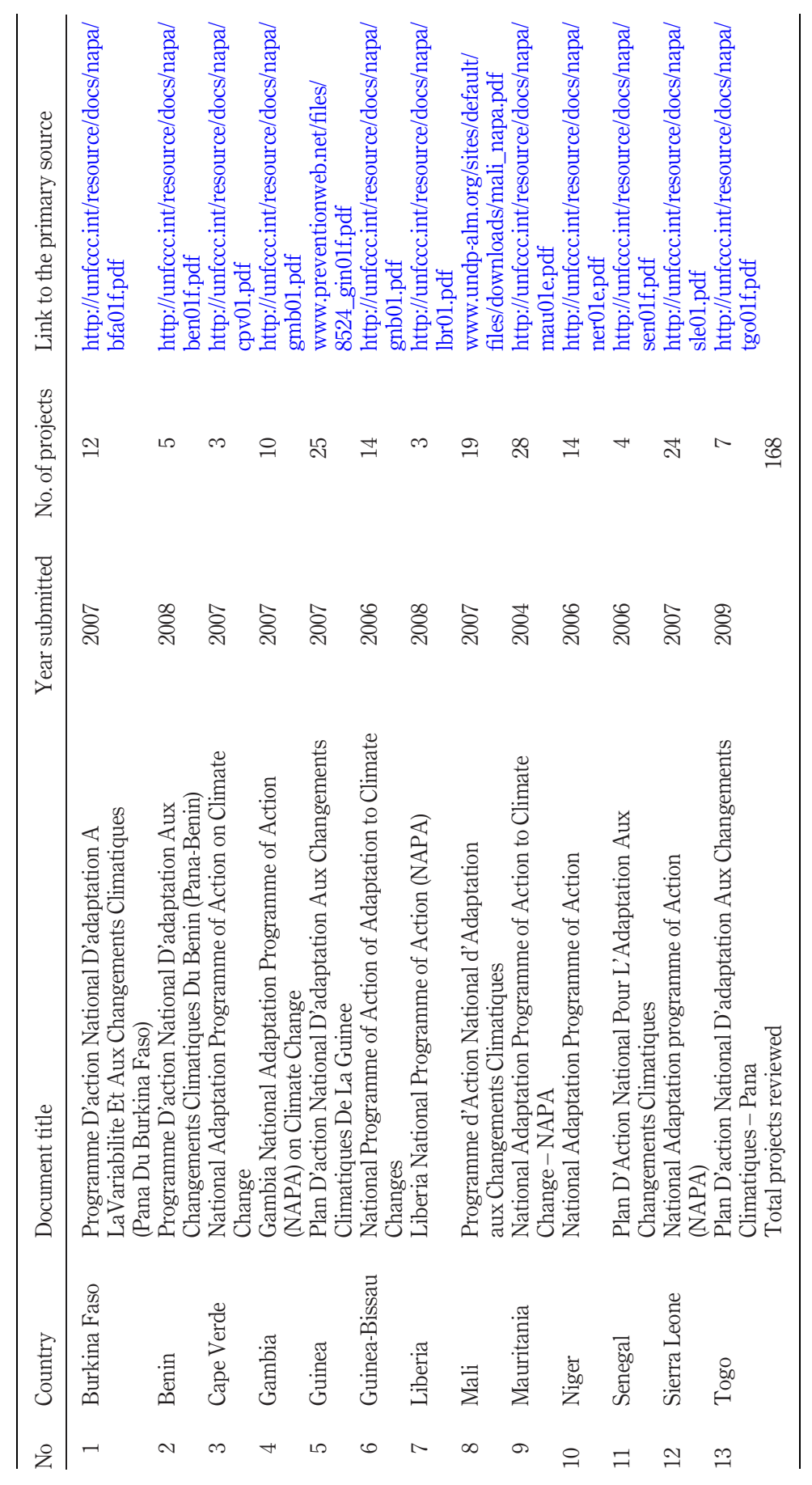

Ecosystem services in adaptation projects

537

Table I. 
IJCCSM

10,4

538

projects expressing one or more ecosystem services indirectly and projects expressing one or more types of ecosystem services directly. This criterion was a modification of a similar benchmark developed by Pramova et al. (2012) and applied in a study by Muthee et al. (2017).

Projects without mentioning ecosystem services are those that failed to express any contribution toward the enhancement of different ecosystem services. These also include those projects which contributed toward the degradation of ecosystems and diminish of the services provided by these ecosystems. They include projects that exploit ecosystems services unsustainably leading to their destruction (for example, unsustainable development initiatives).

Projects that mentioned ecosystem services indirectly are those that contributed toward the indirect enhancement of ecosystem services through activities such as enhancing early warning systems for the communities' adaptation to the effects of climate change. Projects with ecosystem services explicitly mentioned single or multiple ecosystem services as a part of their activities and expected results, such as the provision of fodder, food, habitat, carbon sequestration and recreation services. These projects were divided into the four categories of ecosystem services for analysis.

Figure 2 expounds on the project evaluation criteria and corresponding project classification.

Project description

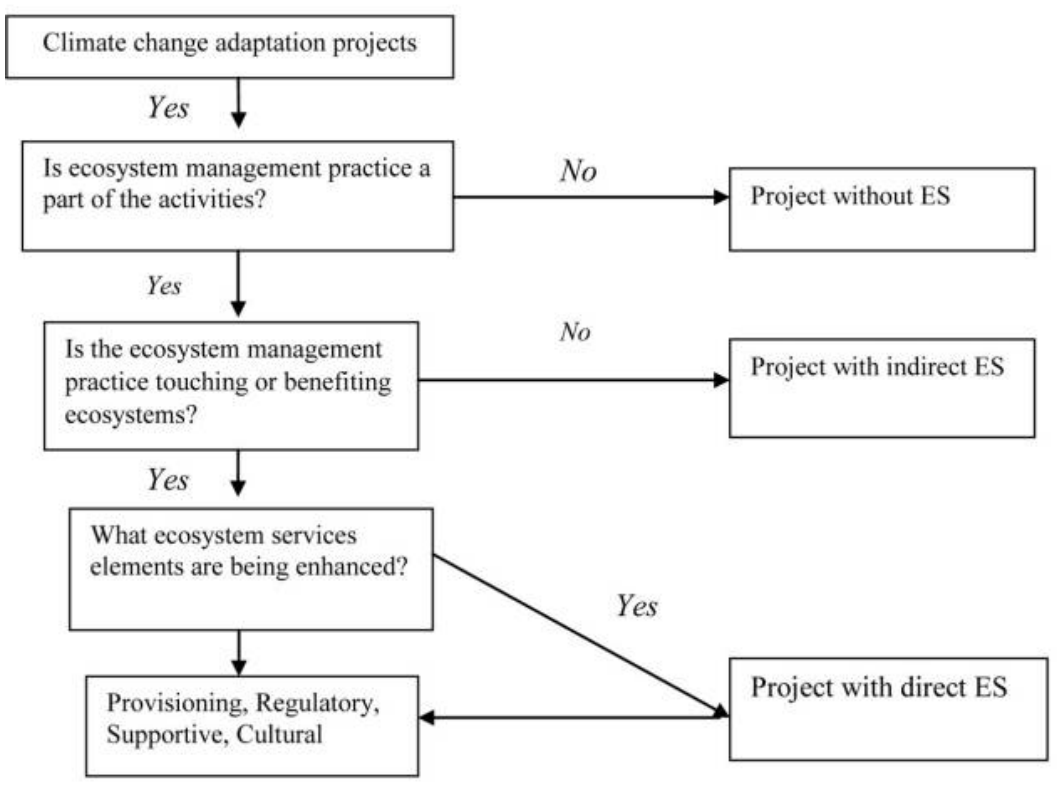

Figure 2.

Project evaluation criteria and classification

\section{Source: Author}

\section{corresponding classification}




\section{Results and discussions}

\subsection{Distribution of adaptation projects in selected West African countries}

The analysis revealed 168 projects distributed across 13 of the 16 countries in West Africa. Mauritania had the biggest number of adaptation projects at 28 while Cape Verde and Liberia had the least at three each. The distribution of the climate change projects per country is summarized in Table I above. The adaptation projects were further analyzed according to their scope of implementation, funding allocation, duration of execution and their thematic areas as discussed in the subsections below. These variations were used in establishing the place of ecosystem services in the adaptation projects studies.

4.1.1 Sector distribution and variation. This study observed that different countries had various areas of priorities based on their contextual needs. Nine thematic areas were established in the studied countries and results summarized as per Table II below. It is notable that the projects varied in terms of their desired outputs, ranging from resources provision projects (for example provision of forestry, water and agricultural services), enabling projects (such as capacity building and cross cutting projects) to human being oriented projects (for example energy and health provision projects). Most of the projects fell within the agricultural thematic area (32 per cent) of the total. This result was consistent with that of Epule et al. (2013) who singled out agriculture as the key area of focus in climate change adaptation due to the historic levels of food insecurity in Africa.

4.1.2 Distribution and variation according to fund allocation. The funds allocation to a given sector is a clear indication of the economic, environmental and social priorities and needs within that country. With the known effects of climate change to the nation economy, it was expected that more funding will be allocated to the adaptation projects to enhance adaptation and mitigation abilities of the ecosystems. From the projects analyzed, the financial allocation ranged from below US\$1m to over US\$4m as summarized in Figure 3 below, indicating low prioritization of the adaptation initiatives.

From the above results, it is evident that there is an insignificant financial investment for adaptation. This is in concurrence with the UNEP Adaptation Finance Gap Report (2016) that pointed out insufficient funds allocation to adaptation measures compared to the magnitude of the challenge posed by climate change in different sectors of the economy. This ultimately exposes the communities and ecosystems to climate change effects, whose cost of adaptation may rise to between 280bn and 500bn by 2050 (UNEP, 2016). Wamunyima and Miga (2014) further note the need for concerted efforts to innovatively increase finances for adaptation to cushion the society from the high economic costs in future as a result of climate change effects.

4.1.3 Distribution and variation based on the project implementation scope. The scope of the projects was established in terms of their proposed geographical and spatial coverage. Projects were classified within the local, sub-national and national distribution. Table III below summarizes the project distribution per country per geographic/spatial scope.

Political boundary context was considered in most projects during the scoping stage. It is notable that the impacts of climate change are essentially local; thus, the adaptation measures should be locally contextualized to address the local transformations. This is achieved through understanding the local needs and challenges, and developing initiatives that solve the local needs largely using the available local resources or expertise. Nalau et al. (2015) note that the management of climate risk can only be realized when the adaptation initiatives are implemented at the local level to support the local communities adapt and mitigate the effects. This cumulatively yields global effects toward adaptation and mitigation. However, the study established that majority of the adaptation exercises are 
IJCCSM

10,4

540

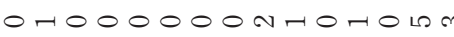

NOO-GーO-mO-NONO

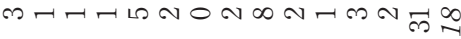

Oronorononotho,

-100-1000m000-100

(1)

Table II.

Projects distribution per country and thematic areas 
within the sub-national and national levels creating havoc in adaptation especially in the wake of Paris agreement and NDCs.

4.1.4 Distribution and variation based on the duration of implementation. Adaptation projects are implemented within a given period after which the project either comes to a close or they are extended depending on the availability of resources and the needs. The project's implementation duration in this study ranged from below one year to over five years. The results are summarized in Table IV below. This considers the distribution of projects by country and by the number of years of implementation.

Ecosystem services in adaptation projects 541

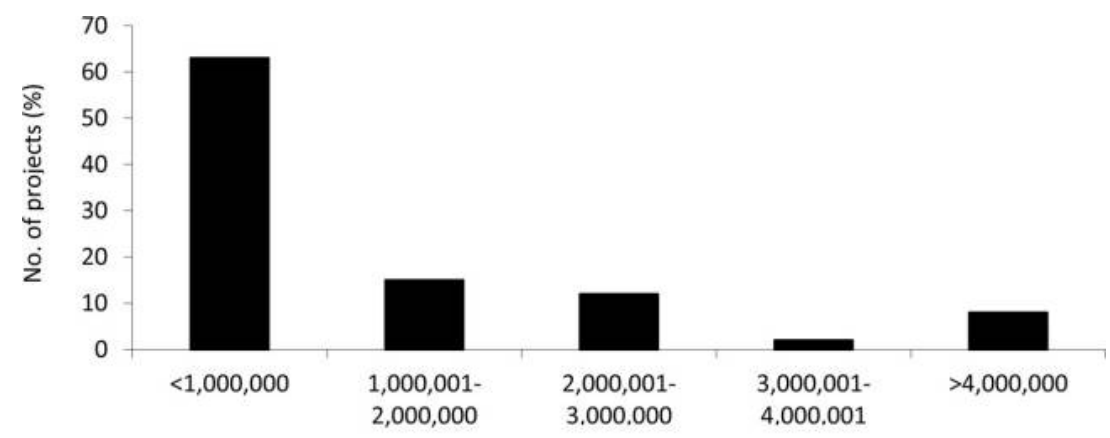

Funds allocation bracket (in USD)

Figure 3.

Project distribution as per fund allocation

\begin{tabular}{lcc}
\hline Scale & No. of projects & No. of projects $(\%)$ \\
\hline Local & 39 & 23 \\
sub-national & 82 & 49 \\
National & 47 & 28
\end{tabular}

Table III.

Projects distribution per scope of implementation

\begin{tabular}{|c|c|c|c|c|c|c|c|c|}
\hline \multirow[b]{2}{*}{ Country } & \multirow[b]{2}{*}{ Total projects } & \multirow[b]{2}{*}{$<1$} & \multirow[b]{2}{*}{2} & \multicolumn{2}{|c|}{ duration (years) } & \multirow[b]{2}{*}{5} & \multirow[b]{2}{*}{$>5$} & \\
\hline & & & & 3 & 4 & & & \\
\hline Burkina Faso & 12 & 0 & 0 & 12 & 0 & 0 & 0 & \\
\hline Benin & 5 & 0 & 0 & 3 & 0 & 1 & 1 & \\
\hline Cape Verde & 3 & 0 & 0 & 0 & 0 & 2 & 0 & \\
\hline Gambia & 10 & 0 & 3 & 3 & 1 & 3 & 0 & \\
\hline Guinea & 25 & 4 & 8 & 7 & 6 & 0 & 0 & \\
\hline Guinea-Bissau & 14 & 0 & 9 & 5 & 0 & 0 & 0 & \\
\hline Liberia & 3 & 0 & 2 & 1 & 0 & 0 & 0 & \\
\hline Mali & 19 & 0 & 7 & 9 & 0 & 3 & 0 & \\
\hline Mauritania & 28 & 0 & 8 & 10 & 1 & 7 & 0 & \\
\hline Niger & 14 & 0 & 11 & 3 & 0 & 0 & 0 & \\
\hline Senegal & 4 & 0 & 1 & 0 & 0 & 3 & 0 & Table I \\
\hline Sierra Leone & 24 & 0 & 1 & 16 & 2 & 5 & 0 & Project distribution \\
\hline Togo & 7 & 0 & 0 & 6 & 1 & 0 & 0 & per country per the \\
\hline Total (No.) & 168 & 4 & 50 & 75 & 11 & 24 & 1 & years of \\
\hline Total $(\%)$ & 100 & 2 & 30 & 46 & 7 & 14 & 1 & implementation \\
\hline
\end{tabular}


IJCCSM

10,4

\section{2}

Adaptation projects fell within short-term, mid-term and long-term implementation periods. It is notable that most of the projects sought to be implemented within a short duration, with 46 per cent falling within three years implementation period. This factor can be attributed to several factors such as inadequate resources to execute the projects for a longer time and insufficient political goodwill from the political class to financially support the adaptation exercises. Boone (2008) noted that most developing countries lack the political leadership and commitment to support adaptation activities in their countries. Ultimately, this exposes the communities to the dangers of climate change effects. This finding also suggests that the planned adaptation is low compared to the scoping strategies put in place.

\subsection{Ecosystem services in the adaptation projects}

4.2.1 Type of ecosystem services provided by the adaptation projects. Ecosystem services are divided into four main categories as established by the MEA (2005) report, namely, provisioning, regulating, supporting and cultural.

4.2.1.1 Provision services. Provision services refers to the products (goods and services) that are obtained from ecosystems. This study identified six provisional services (food provision, water provision, provision of fodder/pasture/forage, provision of non-timber products (such as gum and honey), provision of forest products and provision of fencing products. In all, 84 projects (accounting for 50 per cent of the total number of projects studied) sought to provide diverse provisioning services. Table V below summarizes the types and number of provisioning services provided by the adaptation projects.

4.2.1.2 Support services. Support services refer to those services that support the production of other ecosystem services. The number of projects with ecosystem support services was 16 per cent of the total studied. Some of the established support services include the support of biodiversity, soil formation/productivity/fertility, development of coastal resources and habitats. Among the studied projects, 48 per cent of support services were geared toward enhancing soil formation, enhancing fertility and productivity, support of biodiversity, coastal resources accounted for 21 per cent each, 8 per cent of the projects sought to support habitats while energy and water cycling support accounted for 1 per cent of the total project. These results are summarized in Figure 4 below.

4.2.1.3 Regulating services. Regulating services refer to regulatory benefits from the ecosystems. In all, 42 of the projects studied (accounting for 31 per cent of the total) sought to provide one or more regulatory services. The most mentioned regulatory service is erosion control (water erosion, soil and beach erosion) which appeared in 36 per cent of the projects providing regulatory services. Carbon sequestration was mentioned in 14 per cent of the projects, while disease/pest control and water quality regulation were mentioned in 12 per cent of the total projects. These results are summarized in Figure 5 below.

4.2.1.4 Cultural services. Cultural services refer to nonmaterial benefits such as recreation and spiritual enrichment that people obtain from ecosystems. This study only
Table V.

Provisioning services provided by the adaptation projects
Provisioning services

\begin{tabular}{ccccr}
$\begin{array}{c}\text { Timber } \\
\text { products }\end{array}$ & Water & $\begin{array}{c}\text { Fodder pasture } \\
\text { Forage }\end{array}$ & Food & Total \\
\hline 5 & 19 & 20 & 36 & 84 \\
6 & 23 & 24 & 43 & 100 \\
& & & &
\end{tabular}


established two cultural services, namely, tourism/eco-tourism development and recreational services. The projects providing these services were Coastal Defense System for the Cities of Buchanan and Monrovia: Reducing the vulnerability of coastal urban areas (Monrovia, Buchanan) to erosion, floods, and siltation and degraded landscapes project in Liberia that sought to provide recreational and tourism services through the development and rehabilitation of beaches. Second, Establishment of new Forest Reserves, Protected Areas and National Parks in Sierra Leone project in Sierra Leone sought to promote cultural services by increasing forest cover and biodiversity to attract tourists in the region.

Ecosystem services in adaptation projects

\subsection{Ecosystem services provision in the adaptation projects}

This study categorized climate change adaptation into three categories: projects with direct ES, projects with indirect ES and projects with no ES. The study revealed that 55 per cent of the projects mentioned one or more ES directly as one of the anticipated outcomes, 36 per cent expressed ES indirectly, while 9 per cent either did not express any form of ES or had an adverse impact on ecosystem services. Table VI below summarizes these results.

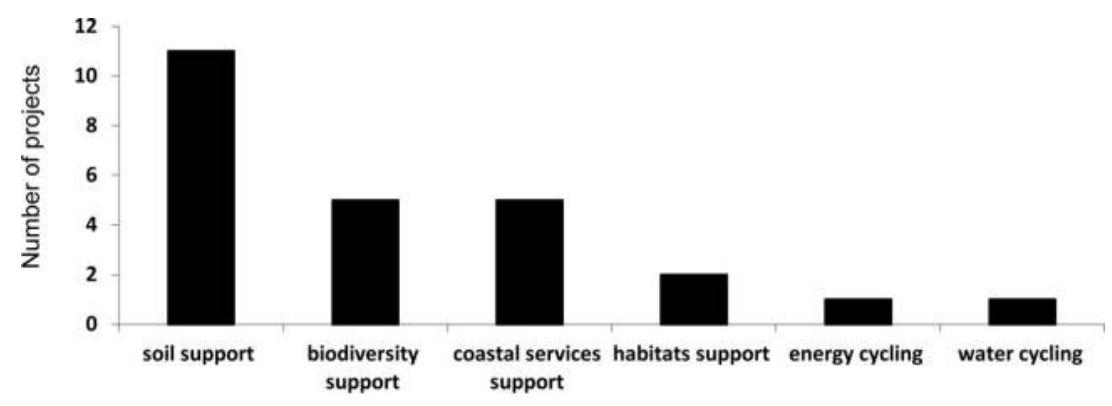

support services provided

Figure 4.

Number of projects that mentioned different types of support services

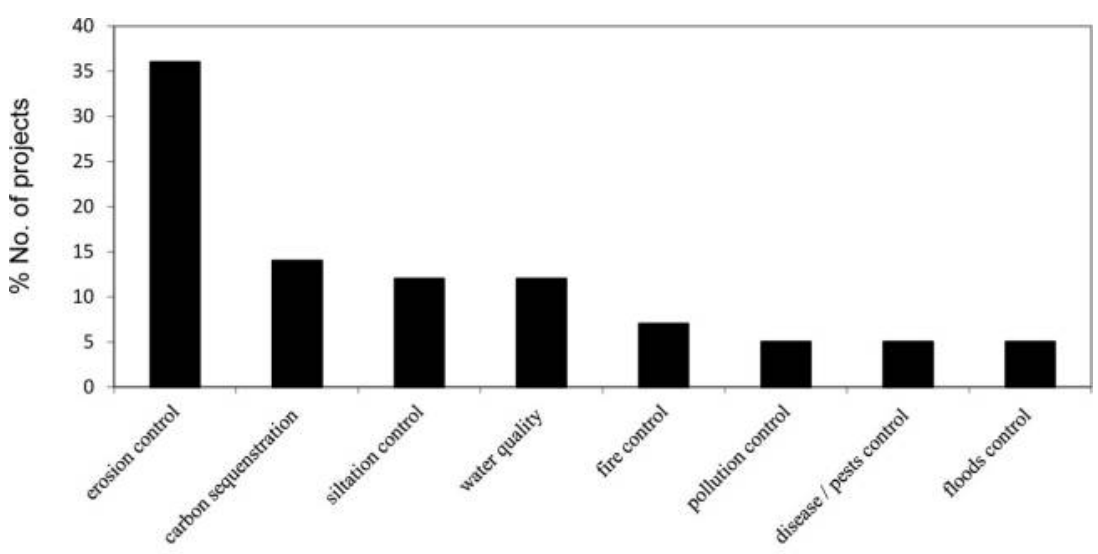

Regulatory services provided

Figure 5.

Number of projects that mentioned different types of regulating services 
IJCCSM

10,4

\section{4}

Table VI.

Ecosystem services provision by the adaptation projects
In Burkina Faso, 75 per cent of the projects mentioned direct ecosystem services, 74 per cent in Mali and 67 per cent in Cape Verde. Mauritania had the highest number of projects with indirect ES components at 60 per cent while Senegal, Sierra Leone and Gambia mentioned ES in 50 per cent of their projects. The last category was projects with no ES or those with negative ES elements. Niger recorded no ES in 21 per cent of their projects, while Benin had 20 per cent.

4.2.1 Projects with direct ecosystem service provision. Projects were said to have direct ecosystem services when they sought to contribute directly toward any of the four forms of ecosystem services (provisioning, regulatory, cultural and supporting). Projects such as Exploitation of surface water as a means to adapt to climate change in the most vulnerable areas in the Centre and North Provinces in Benin sought to directly provide water and control soil erosion and siltation in this study area, while The Expansion and Intensification of Agro-forestry and Reforestation Activities project in Gambia sought to provide biological support and control erosion. These results were in agreement with those of Muthee et al. (2017) which established that most of the adaptation projects in place directly mention or aim to provide different ecosystem services.

4.2.2 Projects with indirect ecosystem service provision. The second category of the projects studied sought to enhance ecosystem services indirectly. Some of the initiatives that fell under the category of indirect ecosystem services included the projects that focused on capacity building and awareness creation in the community so that they are in a better position to adapt to the effects of climate change. Capacity building exercises included community training, and the development of training and learning facilities and materials to increase local knowledge of climate change adaptation. Projects such as Promoting Environmental Education for coastal communities in Guinea and Increase awareness and knowledge on climate change in Senegal sought to contribute toward ecosystem services indirectly through increasing knowledge in the community on climate change adaptation and enhancing the ecosystem services. Additionally, some projects sought to contribute toward enhancing ecosystem services by early warning systems indirectly. Some of the activities put in place included climate monitoring, the establishment of early warning systems, the installation of meteorological, weather and forecast systems, as well as disaster management systems. These included projects such as Mitigating vulnerability to climate change through the strengthening of prevention and food crisis management system in Oursi and Boulsa in Burkina Faso and Rehabilitation of early warning system on climate related natural hazards in Gambia. The need for both direct and indirect elements of ecosystem services is noted in various studies such as Braat and Groot (2012) that established that an informed community is better positioned to adapt to climate change and promote the provision of ecosystem services.

4.2.3 Projects with no ecosystem service provision. The last category of the adaptation projects is those with no ecosystem services. These accounted for 9 per cent of the total projects studied. Projects without ecosystem services have more negative and less positive impacts on ecosystems. Some of the projects studied that had no ecosystem service components included Promotion of income-generating activities and developing mutual

Ecosystem services provision by the adaptation projects

\begin{tabular}{lcccc} 
& Indirect provision & No. ES provision & \\
\hline Number of projects & 92 & 61 & 15 & 168 \\
$\%$ number of projects & 55 & 36 & 9 & 100
\end{tabular}


benefits societies in Niger, Monitoring and control of malaria in the Moyamba districts through the supply of mosquito nets in Sierra Leone and the implementation of a safeguard plan for the town of Nouakchott and its infrastructures in Mauritania. Notably, a significant amount of research has established a link between infrastructure development and ecosystem destruction (Beder, 2002) which poses a major challenge to sustainable development. It is also noteworthy that a majority of projects without ecosystem services are development-oriented as opposed to ecosystem management oriented (Brussard et al., 1998). The study by Raudsepp-Hearne et al. (2010a) pointed out on that the competitive nature of economic development and the environment, noting that it is important to deliberately incorporate the environment into development programs and projects to enhance sustainable development.

\subsection{Projects with single and multiple ES elements}

Projects with single ecosystem service component were designed to achieve one service such as clean water, carbon sinks, flood control or ecotourism services in their lifetime. From those studied, 102 projects (67 per cent) provided a single ecosystem, while 58 projects (33 per cent) mentioned multiple ecosystem services.

The ecosystem services provided were largely determined by the project's thematic areas. For example, a project falling within an agricultural thematic area chiefly provided food as a service, while those within water sector were more likely to provide water or regulation of water quality. Some examples of projects with single ecosystem service outputs included the project titled Fodder crops species introduction in pastoral areas that sought to increase the fodder provision in Niger; and the projects on increasing fish production through aquaculture and conservation of post-harvest in Gambia which sought to increase food production (fish) in Gambia through sustainable aquaculture practices. On the other hand, the project titled The Rural Zones Sanitation and Water-Supply Improvement Project in Guinea-Bissau aimed to provide water (provisional services) as well as to control diseases, especially cholera that results from poor access to water (regulating services). Additionally, the project titled Development of fodder crops in Mauritania aimed to increase the provision of fodder (provisional services) to the livestock by planting diverse fodder species, as well as through the establishment of carbon sinks and carbon fixations (regulating services). The Protection of riversides and restoration of silted up ponds project in Niger sought to provide multiple ecosystem services, notably the provision of water for both livestock and farming needs (provisional services) while fighting against the siltation of water ponds (regulating services).

Most of the projects are single sectored, which hinders them from realizing their full potential that comes when integrating the multi-sectoral approaches. Several reasons can be attributed to single-sectored projects, chiefly the lack of adequate resources to incorporate all of the stakeholders and sectors involved in a given ecosystem as well as limited time frame for implementation. Studies such as Muthee et al. (2017) established that integrating different sectors and stakeholders within adaptation projects is likely to yield better and more sustainable results as opposed to single-sectored projects. Integrating the various sectors also contributes toward multiple benefits within a single ecosystem. In addition, ecosystems are characterized by the interplay among its various components such as water, forests and agricultural land; hence, there is a need to develop an integrated approach that meets the diverse need from these sectors and thematic areas. 
IJCCSM

10,4

\subsection{Areas recommended for redesign and improvement of climate change adaptation projects}

This study revealed that there are various areas of possible redesign and improvement with an aim to support adaptation at the local community level. The projects were categorized and analyzed as per their thematic areas to reveal areas of improvement and redesign to enhance community adaptation and climate change mitigation.

4.4.1 Recommendations for improvements regarding adaptive capacities. The CRiSTAL tool showed various ways in which the studied projects can be redesigned to improve the community's adaptive capabilities. One of the ways is by strengthening the ability of natural resources to help in the adaptation process and enhancing societal livelihoods through initiatives such as conserving soils, forests and water resources. Through this, ecosystems restore their ability to provide ecosystem services that benefit the communities in the long run by increasing the adaptation assets. Projects such as Restoration and management of Oursi pond in Burkina Faso and Exploitation of surface water as a means to adapt to climate change in the most vulnerable areas in the Centre and North Provinces in Benin revealed that adding activities related to strengthening natural resources improves the ability of ecosystems to function and at the same time aids the community in adaptation process in the long run. Some of the additional redesigning activities recommended include the conservation of the riparian zones, re-afforestation in the catchment areas and sustainable farming by the small-scale farmers to help conserve water resources. These findings were in line with the research conducted by Raudsepp-Hearne et al. (2010b) that pointed out the need for ecosystems conservation and management as a way of promoting their adaptation capabilities. Further, the IPCC (2014b) report that increasing consideration of the natural benefits ultimately increases the adaptation assets to the communities in the long run.

This study also portrayed the fundamental role that is played by alternative livelihoods that are less dependent on natural resources as a way of adaptation. The analysis revealed that most communities are entirely dependent on natural resources for their existence. This has, over the years, led to low levels of adaptation and the depletion of natural resources. A case in this study is the Integrated protection and management of Coastal Zones project in Cape Verde that revealed that overreliance of the coastal zones and marine resources had led to their depletion over time, necessitating a form of alternative lifestyles that are less dependent on these resources and are more sustainable long-term. This study revealed that investment in activities such as ecotourism that are less destructive to ecosystems is ideal for enhancing community adaptation to the climate changes and promoting ecosystem functionality. This corroborates with the study by Muthee et al. (2017). Besides, alternative lifestyles should also incorporate resource management activities such as reforestation, coastal zone management and marine biodiversity conservation. This finding is also supported by research conducted by Farley and Costanza (2010) that analyses how payment for ecosystem services can be used as an alternative in the conservation of natural resources and the promotion of community adaptation.

Investment in sustainable agriculture was also identified as critical area of potential improvement for adaptation projects. This study established that most agricultural projects were conducted on a small scale, but their combined impacts on ecosystems were immense. This necessitated practices that are less destructive to the ecosystem at small-scale levels, including soil conservation and management, the use of farm and organic manure and conservation agriculture that is less harmful to the environment while still increasing the agricultural productivity. Other measures identified include intercropping and mixed cropping that not only increase productivity but also enhance conservation. Some of the 
projects within this sector include Diversification and Intensification of Agricultural Production, Processing, and Marketing in Gambia and Implementation of irrigated rice cultivation in Moyenne and Haute Guinea in Guinea. Both all pointed out the need for sustainable agricultural measures and approaches for adaptation.

Financial investment was also established as a key factor in adaptation measures and projects. The available resources largely determine the ability to conserve ecosystems and benefits from their services. Research by Wamunyima and Miga (2014) pointed out that financial constraints are a major hindrance to effective adaptation. The analysis revealed that there is a need for more financial investment in building the knowledge and capacity of the small-scale farmers to adapt in to climate change effects. This can be ensured through opening up private institutions, microfinance and insurances to the farmers to reduce climate vulnerability. UNEP (2016) also notes that there is the need for increased financial investment from private equities toward the GCF to enhance adaptation. This proposition also agrees with the Paris Agreement on the innovative ways of raising adaptation funds, through creative initiatives such as private investments to adaptation.

The last aspect of adaptation is through human resources capacity development. The analysis revealed that there is a need for capacity building through practical training and demonstration on adaptation options. Some of the technologies include sustainable fishing, water utilization, forestry management and marine biodiversity conservation. In this study, projects such as Increase awareness and knowledge on climate change in Senegal and Support and assistance to the rural communities of the regions of Savanes and Plateaux to prevent and fight vector borne diseases in Togo demonstrated the role of capacity development as a method of community adaptation. However, only 10 per cent of these projects mentioned capacity building and development portraying a significant gap that needs to be bridged so that communities have the right set of skills and experience when it comes to promoting ecosystem services using different projects. This is well illustrated in the UNEP (2016) Adaptation Gap Report that points out technology and knowledge gaps among the main challenges to adaptation.

4.4.2 Recommendations for improvements regarding mitigation capacities. Mitigation entails cutting down emissions by creating and improving carbon sinking abilities within the projects. Notably, greenhouse emissions were not considered as a primary concern to the communities based on their minimal emitting capacities.

This study, however, noted that mitigation could increase the project's impacts when synergized with adaptation measures. Mitigation measures such as increasing tree cover and soil management to promote their ability to act as carbon sinks contribute to enhancing the ecosystems resilience to the effects of climate change. Mitigation approaches can also improve the community livelihoods through the sale of carbon credits and payments through Reducing Emissions from Deforestation and Forest Degradation in Developing Countries (Chomba et al., 2016). Financing mechanisms through mitigation measures can also aid in promoting adaptation and ecosystem functionality through conservation, ecosystem rehabilitation and improving the livelihoods of the communities. This can be a step toward poverty eradication through adaptation projects.

This study also revealed that mitigation could be achieved by enhancing sustainability in the energy sector, accounting that accounted for about 5 per cent of the surveyed projects. Energy usage remains one of the leading contributors to climate change globally. Mitigation measures such as the usage of the renewable energy sources like solar and wind can contribute toward mitigation. Projects such as Promotion of the use of renewable energy (Solar Energy) in Sierra Leone and improvement of energy efficiency and conservation of energy resources and Energy Promotion from Typhaaustralis portrayed the fundamental 
IJCCSM

10,4

\section{8}

role played by alternative energy sources in mitigating the effects of climate change, community adaptation and the conservation of forest resources that are heavily exploited for energy. Other projects such as Promoting the use of energy saving equipment (improved stoves, M'Bora stew pan) and renewable energy-based technologies (pressure-cooker, water heater, and solar dryers, etc.) in Burkina Faso sought to mitigate climate change by improving cooking stove, which at the same time reduced the community exposure to health hazards.

\section{Conclusions and recommendations}

In conclusion, the study assessed the status of ecosystem services on a climate change context by reviewing 168 projects from 13 West Africa countries and established the projects' redesigning options by subjecting them to the CRiSTAL tool. The projects fell in three broad categories: resources oriented projects that seek to provide one or more resources (for example, water, forest, coastal resources and agriculture), enablers oriented (for example, capacity building, early warning systems and cross cutting) and human wellbeing oriented (for example, energy and health provision). This study revealed that the investigated adaptation projects vary in terms of the scope of implementation, duration, thematic area and ecosystem services provided by the projects. It is notable that the fundamental determinant of the adaptation approach taken is the sector where the project falls, with the majority (32 per cent) falling in the agricultural sector. A common impediment is low budgetary allocation and reliance on foreign sources of funding with most of the support originating from outside the country of implementation. Furthermore, there are minimal considerations to the complexity of ecosystems when designing many of the investigated adaptation projects. The study determined that different countries had various areas of priorities based on their contextual needs.

The study recommends more integration of ecosystem services in different projects in the various sectors studied. This inclusion will play an essential role in promoting suitability of the adaptation projects and improving their ability to meet the ecosystems and societal needs in the long run. It also recommends more financial commitment from both within and outside by West African countries which are among the most affected by climate change effects. This can be achieved through partnership and collaborations among the state organs, private sectors, among other players to generate an amicable solution to the consequences of climate change. Further, political goodwill is also an important aspect in combating climate change effects in West Africa. The study explored incorporation of ecosystem services in the adaptation projects. Lastly, the study recommends more investment in both time and resources to realize multiple outputs and ecosystem services from a single project. This calls for a multi-sectoral approach in project design and execution to enhance the project sustainability and benefits. An integrated approach would be ideal for enhancing ecosystem services in the adaptation projects put in place.

\section{References}

Bailey, R. (2009), Ecosustems Geography, 2nd ed., Springer Publishers, New York, NY.

Beder, S. (2002), “Economy and environment: competitors or partners?”, Pacific Ecologist, Vol. 3, pp. 50-56.

Boone, C. (2008), "Environmental justice as process and new avenues for research", Environmental Iustice, Vol. 1 No. 3, pp. 149-154.

Boyd, J. and Banzaf, S. (2007), "What are ecosystem services? the need for standardizedEnvironmental accounting units", Ecological Economics, Vol. 63 Nos 2/3, pp. 616-626. 
Braat, L. and Groot, R. (2012), "The ecosystem services agenda: bridging the worlds of natural sciences and economics, conservation and development, and public and private policy", Ecosvstem Services, Vol. 1 No. 1, pp. 4-15.

Brouwer, R., Tesfaye, A. and Pauw, P. (2011), "Meta-analysis of institutional-economic factors explaining the environmental performance of payments for watershed services", Environmental Conservation, Vol. 38 No. 4, pp. 380-392.

Brussard, F., Reed, J. and Tracy, C. (1998), "Ecosystem management: what is it really?", Landscape and Urban Planning, Vol. 40 Nos 1/3, pp. 9-20.

Ecosystem services in adaptation projects

Capistrano, D. (2005), "Ecosystems and human well-being: multistage assessments. Findings of the Sub-global assessments working group of the millennium ecosystem assessment", The Millennium Ecosystem Assessment, Vol. 4, pp. 1-51.

CCSP (2008), "Preliminary review of adaptation options for climate-sensitive ecosystems andresources", A Report by the US Climate Change Science Program and the Subcommittee on Global Change Research, [Julius, S.H., J.M. West (eds ), J.S. Baron, L.A. Joyce, P. Kareiva, B.D. Keller, M.A. Palmer, C.H. Peterson, and J.M. Scott (Authors)], U.S. Environmental Protection Agency, Washington, DC.

Chomba, S., Kariuki, J., Lund, J. and Sinclair, F. (2016), "Roots of inequality: how the implementation of REDD + reinforces past injustices", Land Use Policy, Vol. 50, pp. 202-213.

Colls, A., Ash, N. and Ikkala, N. (2009), Ecosystem Based Adaptation: A Natural Response to Climate Change, Welcome to Cristal tool, IUCN, Gland, available at: www.iisd.org/cristaltool/(accessed 12 March 2016).

Epule, E., Pend, C., Lepage, L. and Chen, Z. (2013), The Causes, Effects and Challenges of Sahelian Droughts: A Critical Review, Springer-Verlag Publishers, Berlin.

Farley, J. and Costanza, R. (2010), "Payment for ecosystem services: from global to local", Ecological Economics, Vol. 69 No. 11, pp. 2060-2068.

IPCC (2007), "Climate Change 2007: synthesis Report", Contribution of Working Groups I, II and III to the Fourth Assessment Report of the Intergovernmental Panel on Climate Change, IPCC.

IPCC (2014a), in Edenhofer, O., Pichs-Madruga, R., Sokona, Y., Farahani, E., Kadner, S., Seyboth, K., Adler, A., Baum, I., Brunner, S., Eickemeier, P., Kriemann, B., Savolainen, J., Schlömer, S., von Stechow, C., Zwickel, T. and Minx, J.C. (Eds), Climate Change 2014: Mitigation of Climate Change. Contribution of Working Group III to the Fifth Assessment Report of the Intergovernmental Panel on Climate Change, Cambridge University Press, Cambridge.

IPCC (2014b), 'Climate Change 2014: Synthesis Report. Contribution of Working Groups I, II and III to the Fifth Assessment Report of the Intergovernmental Panel on Climate Change', [Core Writing Team, Pachauri, R.K. and Meyer, L.A. (Eds)], IPCC, Geneva, p. 151.

Lomborg, B. (2016), "Impact of current climate proposals", Global Policv, Vol. 7 No. 1, pp. 109-118.

Melillo, J., Field, C. and Moldan, B. (2003), 'Interactions of the Major Biogeochemical Cycles, Island Press, Washington, DC.

Michelle, D., Grimm, N., Staudt, A., Carter, S., Stuart, F., Kareiva, P., Ruckelshaus, M. and Stein, B. (2012), "Impacts of climate change on biodiversity, ecosystems, and ecosystem services", Technical Input to the 2013 National Climate Assessment.

Millennium Ecosystem Assessment - MEA (2005), Ecosystems and Human Well-Being: Synthesis, Island Press, Washington, DC.

Muchuru, S. and Nhamo, G. (2017), "Climate change and the African livestock sector: emerging adaptation measures from UNFCCC national communications", International Journal of Climate Change Strategies and Management, Vol. 9 No. 2, pp. 241-260, available at: https://doi.org/ 10.1108/IJCCSM-07-2016-0093

Munang, R. (2013), "The role of ecosystem services in climate change adaptation and disaster risk reduction", Current Opinion in Environmental Sustainability, Vol. 5 No. 1, pp. 47-50. 
IJCCSM

10,4

550

Muthee, K., Mbow, C., Macharia, G. and Leal Filho, W. (2017), "Ecosystem-Based Adaptation (EbA) as an adaptation strategy in Burkina Faso and Mali”, in Leal Filho, W., Simane, B., Kalangu, S., Menas, W., Munishi, P. and Musiyiwa, K. (Eds), Climate Change Management, Springer Publishers, London, pp. 205-215.

Nalau, J., Pretson, B. and Maloney, M. (2015), “Is adaptation a local responsibility?”, Environmental Science \& Policy, Vol. 48, pp. 89-98.

Pramova, E., Locatelli, B., Brockhaus, M. and Fohlmeister, S. (2012), "Ecosystem services in the national adaptation programmes of action", Climate Policy, Vol. 12 No. 4, pp. 393-409.

Raudsepp-Hearne, C., Peterson, D., Tengö, M., Bennett, M., Holland, T., Benessaiah, K., MacDonald, M. and Pfeifer, L. (2010a), "Untangling the environmentalist's paradox: why is human well-being increasing as ecosystem services degrade?”, BioScience, Vol. 60 No. 8, pp. 576-589.

Raudsepp-Hearne, C., Peterson, G. and Bennett, E. (2010b), "Ecosystem services bundles for analyzing tradeoffs in diverse landscapes", Sustainability Science, Vol. 107 No. 11, pp. 5242-5247.

UNCTAD (2014), "The Least Developed Countries Report 2014", Growth with structural Transformation: A Post-2015 Development Agenda, available at: http://unctad.org/en/ PublicationsLibrary/ldc2014 en.pdf(accessed 15 June 2016).

UNEP (2016), The Adaptation Finance Gap Report 2016, United Nations Environment Programme (UNEP), Nairobi.

Wamunyima, M. and Miga, W. (2014), 'Assessment of adaptation financial flows in Zambia.' Consultancy report prepared for AFAI in Zambia, Unpublished Research.

\section{Corresponding author}

Kennedy Wahome Muthee can be contacted at: kenwahome@gmail.com

For instructions on how to order reprints of this article, please visit our website: 